\title{
Growth factor signaling and memory formation: temporal and spatial integration of a molecular network
}

\author{
Ashley M. Kopec ${ }^{1}$ and Thomas J. Carew \\ Center for Neural Science, New York University, New York, New York 10003, USA
}

\begin{abstract}
Growth factor (GF) signaling is critically important for developmental plasticity. It also plays a crucial role in adult plasticity, such as that required for memory formation. Although different GFs interact with receptors containing distinct types of kinase domains, they typically signal through converging intracellular cascades (e.g., Ras-MEK-MAPK) to mediate overlapping functional endpoints. Several GFs have been implicated in memory formation, but due to a high level of convergent signaling, the unique contributions of individual GFs as well as the interactions between GF signaling cascades during the induction of memory is not well known. In this review, we highlight the unique roles of specific GFs in dendritic plasticity, and discuss the spatial and temporal profiles of different GFs during memory formation. Collectively, the data suggest that the roles of GF signaling in long-lasting behavioral and structural plasticity may be best viewed as interactive components in a complex molecular network.
\end{abstract}

Beginning with the pioneering discoveries of Rita Levi-Montalcini, Stanley Cohen, and Victor Hamburger in the 1950s, it is now fully appreciated that growth factors (GFs) are secreted molecules which bind membrane-associated extracellular receptors, thereby activating intracellular signaling cascades that ultimately mediate cellular survival and growth. The first GF that was fully characterized was nerve growth factor (NGF) (Cohen et al. 1954; Levi-Montalcini et al. 1996). Since then, it has become apparent that there are several families of growth factors, and they can be categorized by the signaling mechanism engaged by their receptor. The two major classes of receptors are receptor tyrosine kinases and serine-threonine kinases. GFs that signal through receptor tyrosine kinases include the epidermal growth factor (EGF) family (Prenzel et al. 2001), the fibroblast growth factor (FGF) family (Turner et al. 2006), the platelet-derived growth factor (PDGF)/vascular endothelial growth factor (VEGF) superfamily (Hoch and Soriano 2003; De Almodovar et al. 2009), hepatocyte growth factor (HGF) (Nakamura et al. 2011), and the neurotrophin family, which includes NGF, brain-derived neurotrophic factor (BDNF), neurotrophin 3 (NT-3), and neurotrophin 4/5 (NT-4/5) (Huang and Reichardt 2003; Park and Poo 2013). Those GFs that signal through serine-threonine kinases include the transforming growth factor $\beta$ (TGF $\beta$ ) superfamily including TGF $\beta$, activin, and bone morphogenic proteins (BMPs) (Massague 2000; Krieglstein et al. 2011). There are also families with mixed signaling mechanisms such as the insulin family, including insulin and insulin-like growth factor 1 (IGF1), which signal through receptor tyrosine kinases, and insulin-like growth factor 2 (IGF2), whose primary receptor, IGF2/M6P receptor (also known as the cation-independent mannose 6-phosphate receptor), does not have intrinsic kinase activity (Hawkes and Kar 2004; Taniguchi et al. 2006).

Although there are a wide variety of GFs and distinct receptors that constitute different GF families, there is considerable overlap in the roles that different GFs play as critical mediators of developmental plasticity. For example, GFs are important for promoting cell survival, neurogenesis, differentiation, axon outgrowth, dendritic growth and maturation, synaptogenesis, and activitydependent synaptic pruning (Hoch and Soriano 2003; Hawkes

\footnotetext{
${ }^{1}$ Corresponding author

Email amk650@nyu.edu

Article is online at http://www.learnmem.org/cgi/doi/10.1101/lm.031377.113.
}

and Kar 2004; De Almodovar et al. 2009; Krieglstein et al. 2011; Nakamura et al. 2011; Park and Poo 2013). Surprisingly, different GF families mediate these diverse effects by engaging translation and transcription through highly converging signaling cascades, such as Ras-MEK-MAPK, PI3K-AKT, and CREB-mediated transcription (Finkbeiner et al. 1997; Massague 2000; Prenzel et al. 2001; Huang and Reichardt 2003; Taniguchi et al. 2006; De Almodovar et al. 2009; Acebes and Morales 2012).

In recent years, it has become clear that many of the canonical GF signaling cascades that are engaged during development are reengaged to support plasticity in the adult. A major form of such plasticity is involved in the induction of learning and memory. Memory can exist in a wide range of temporal domains that can be distinguished not only by the duration of the memory, but also by the molecular mechanisms that are engaged in their induction and maintenance. Short-term memory is mediated by posttranslational modifications, and lasts on the order of minutes (Castellucci et al. 1989; Xia et al. 1998). Intermediate-term memory requires protein translation and can last several hours (Sutton et al. 2001; Stough et al. 2006), and long-term memory (LTM) requires both protein translation and de novo gene expression, and lasts for days, months, even a lifetime (Castellucci et al. 1989; Bailey et al. 1996; Sangha et al. 2003; Reissner et al. 2006). In addition to translation and transcription, both LTM and its mechanistic correlate, long-term synaptic strengthening (often termed long-term potentiation [LTP] or long-term facilitation $[\mathrm{LTF}])$, are correlated with dendritic growth and remodeling and synaptogenesis (Lamprecht and LeDoux 2004; Bailey and Kandel 2008; Caroni et al. 2012). Additionally, Ras-MEK-MAPK, PI3KAKT, and CREB-mediated transcription are all critically important for LTP/LTF and LTM (Bourtchuladze et al. 1994; Yin et al. 1994; Martin et al. 1997; Atkins et al. 1998; Lin et al. 2001; Opazo et al. 2003; Sweatt 2004; Horwood et al. 2006; Lee et al. 2008; Sui et al. 2008; Won and Silva 2008; Alberini 2009). Thus, it is not surprising that a wide range of GFs are implicated as having a critical role in long-lasting plasticity (Abe et al. 1991; Ishiyama et al. 1991; Gutierrez et al. 1997; Zhang et al. 1997; Park et al. 2000; Egan et al. 2003; Sharma et al. 2006; Zhao et al. 2007; Conner et al. 2009; Ageta et al. 2010; McNay et al. 2010; Peng et al. 2010; Chen et al. 2011; Mauceri et al. 2011; Kato et al. 2012; Shioda et al. 2012). There are, however, some conflicting reports for the role of specific GFs in long-lasting plasticity. For example, NGF 
has been demonstrated to be necessary for spatial learning, conditioned taste aversion, and inhibitory avoidance (IA) memory in adult rats (Gutierrez et al. 1997; Conner et al. 2009). However, conditional deletion of $N G F$ or TrkA in young or intermediate-aged mice did not significantly impair memory for passive avoidance, contextual fear conditioning, or cued fear conditioning (Muller et al. 2012). These data indicate that the role of GFs in specific forms of memory may be more complicated than previously appreciated.

In addition to distinguishing between distinct GF roles in development, compared to their roles in established adult circuitry, rapid progress in this general field raises several important questions. For example, it will be important (1) to determine whether GFs are engaged differentially by different forms of learning and in different brain regions; (2) to establish whether and how GF contributions to long-lasting plasticity change across the lifespan; and (3) to elucidate the relative contributions of individual GFs to learning and memory formation. Because converging signaling cascades are often engaged by different GFs, and phenotypically similar functional outcomes are often induced by different GFs (and even different GF families), the relative contribution of each individual GF is difficult to determine. Are all GFs engaged during learning and memory formation? Does each GF uniquely contribute to a critical aspect of learning and memory? And, if they all mediate similar outcomes through converging signaling cascades, what is the functional significance of more than one GF in the induction of learning and memory?

The central theme of this review is that individual GFs mediate distinct functional outcomes by engaging temporally and spatially regulated signaling cascades. To develop this theme, we will first review data implicating GFs in unique aspects of adult dendritic plasticity. We will then focus on GF regulation of RasMEK-MAPK signaling and the distinct spatial and temporal profiles of GFs engaged during plasticity, which could mediate unique functional end points. Finally, we will highlight the fact that a single form of GF signaling does not occur in isolation from other GFs and their signaling cascades. We thus propose that the wide array of GFs implicated in plasticity is best viewed as interactive elements in a complex molecular network.

\section{Dendritic plasticity}

Dendritic plasticity is a fundamental mechanism underlying synaptic strengthening, and is thought to be a critical substrate for the acquisition and consolidation of long-term memories (Bailey and Kandel 1993; Yang et al. 2009). Moreover, dendritic plasticity is not limited to a single brain region; rather, it has been observed in a number of both cortical and subcortical structures (Knafo et al. 2001; Lee et al. 2007; Hofer et al. 2009; Restivo et al. 2009; $\mathrm{Xu}$ et al. 2009; Yang et al. 2009; Roberts et al. 2010). Dendrites are highly dynamic and can be modulated by changes in the length of the neck of the spine, by volume changes within the dendrite itself, by dendritic turnover, or by the loss and/or addition of dendrites. All of these forms of dendritic plasticity occur during adult learning and memory (Lamprecht and LeDoux 2004; Segal 2005). Hippocampal-dependent memories are thought to undergo "systems consolidation," in which storage of the memory over time becomes less dependent on hippocampal structures and more dependent on cortical regions (Frankland and Bontempi 2005). Importantly, dendritic changes in the cortex correlate well with the time frame of systems consolidation (Restivo et al. 2009). Thus, dendritic plasticity provides an excellent candidate mechanism as a platform for studying the acquisition, consolidation, and storage of LTM. Not surprisingly, GFs are critical regulators of adult dendritic plasticity (Horch et al. 1999; Withers et al. 2000; Horch and Katz 2002; Zheng et al. 2003; Dijkhuizen and Ghosh 2005; Ji et al. 2005; Shoji-Kasai et al. 2007; Chiu et al. 2008; Tanaka et al. 2008; Mauceri et al. 2011; Schmeisser et al. 2012; Shioda et al. 2012). Perhaps more surprising is the fact that not all GFs regulate the same aspects of dendritic plasticity (Table 1).

Table 1. GF regulation of dendritic plasticity

(A) Dendritic and synaptic density

\begin{tabular}{|c|c|}
\hline \multicolumn{2}{|c|}{ Tyrosine kinase } \\
\hline PDGF & $\begin{array}{l}\text { Increased dendrites in CA1 of PDGF } \beta-R \text { KO } \\
\text { mice (Shioda et al. 2012) }\end{array}$ \\
\hline VEGF & $\begin{array}{l}\text { No change (no rescue) in spine density in } \\
\text { mice with nuclear CaM signaling } \\
\text { deficiency (Mauceri et al. 2011) }\end{array}$ \\
\hline BDNF & $\begin{array}{l}\text { Increased dendrites in cortical and } \\
\text { hippocampal culture (Dijkhuizen and } \\
\text { Ghosh 2005; ji et al. 2005) }\end{array}$ \\
\hline & $\begin{array}{l}\text { Increased dendrites in cortical slice (Horch } \\
\text { et al. 1999) }\end{array}$ \\
\hline \multicolumn{2}{|c|}{ Serine-threonine kinase } \\
\hline TGF $\beta$ & $\begin{array}{l}\text { Increased synaptogenesis in cortical culture } \\
\text { (Diniz et al. 2012) }\end{array}$ \\
\hline \multicolumn{2}{|r|}{ (2) } \\
\hline \multicolumn{2}{|l|}{ BMP } \\
\hline \multicolumn{2}{|c|}{ Mixed signaling mechanisms } \\
\hline Insulin & $\begin{array}{l}\text { Decreased synaptic density and no change } \\
\text { in synapse maturation in Xenopus tectal } \\
\text { neurons transfected with DN IR (Chiu } \\
\text { et al. 2008) }\end{array}$ \\
\hline IGF2 & $\begin{array}{l}\text { Increased (rescued) synaptic density and } \\
\text { increased (rescued) spine maturation in } \\
\text { mouse forebrain with deficient NF-кB } \\
\text { signaling (Schmeisser et al. 2012) }\end{array}$ \\
\hline
\end{tabular}

(B) Dendritic length and volume

No change in length in CA1 of PDGF $\beta-R$ KO mice (Shioda et al. 2012)

Increased (rescued) length in mice with nuclear CaM signaling deficiency (Mauceri et al. 2011)

No change in length in cortical culture (Dijkhuizen and Ghosh 2005)

Increased volume and decreased length in CA1 of hippocampal slice (Ji et al. 2005)

Increased length in hippocampal culture (Shoji-Kasai et al. 2007)

Increased length in hippocampal culture (Withers et al. 2000)

(C) Dendritic complexity

No change in CA1 of PDGF $\beta$-R KO mice (Shioda et al. 2012)

Increased (rescued) in mice with nuclear $\mathrm{CaM}$ signaling deficiency (Mauceri et al. 2011)

No change in cortical culture (Dijkhuizen and Ghosh 2005)

Increased in cortical slice (Horch et al. 1999; Horch and Katz 2002)

No change in cortical culture (Diniz et al. 2012)

Increased in hippocampal culture (Withers et al. 2000)

(KO) Knockout, (IR) insulin receptor, (DN) dominant negative. 
Thus, in this review, we use dendritic plasticity as a vehicle to discuss GF signaling for three reasons: (1) it is a well-described component of LTM, (2) it occurs in virtually every brain region implicated in memory formation and storage, and (3) it provides an area that differentiates roles of specific GFs in different components of structural plasticity.

\section{GF regulation of dendritic and synaptic density (outlined in Table 1A)}

Mice with mutations in the PDGF $\beta$ receptor show decreased apical and basal dendrites in the hippocampus, as well as impaired spatial memory (Shioda et al. 2012). However, spine length and dendritic arborization in these mice are similar to control mice (Shioda et al. 2012), indicating that PDGF is important for the number of dendrites, but not for other aspects of dendritic morphology. Similarly, insulin signaling has been shown to support a dissociation in Xenopus tectal neurons transfected with a dominant negative insulin receptor (Chiu et al. 2008). These neurons have reduced synapse density and altered activity-dependent dendritic plasticity, but show no difference in synapse maturation (as measured by the area of the presynaptic terminal clustered with vesicles [Chiu et al. 2008]). Another member of the insulin family, IGF2, rescues synapse density and promotes spine maturation in mouse forebrain neurons with a mutation in nuclear factor $\kappa \mathrm{B}$ (NF-кB) (Schmeisser et al. 2012). Intriguingly, impairments in synaptic signaling due to mutations of NF- $\mathrm{kB}$ signaling are rapidly reversible (within $1 \mathrm{wk}$ of rescue of NF-кB signaling or within $24 \mathrm{~h}$ of IGF2 application), suggesting that this is a highly dynamic regulatory process (Schmeisser et al. 2012).

In cultures of cortical neurons, BDNF increases the number of primary dendrites but not arborization or total dendritic length (Dijkhuizen and Ghosh 2005). Conversely, BDNF increases both dendritic growth and arborization in cortical neuron slice preparation (Horch et al. 1999; Horch and Katz 2002), indicating that BDNF signaling may be different between neurons in culture and those in slice preparations. Finally, in dissociated cultures of mature hippocampal neurons, BDNF increases spine density and the number of primary dendrites, but only the former effect required cAMP (Ji et al. 2005), suggesting that BDNF engages distinct molecular signaling to mediate different structural effects.

\section{GF regulation of dendritic length and volume (outlined in Table 1B)}

A TGF $\beta$ superfamily member, activin, increases the length of dendritic spine necks in a MEK-dependent manner in low-density rat hippocampal cultures (Shoji-Kasai et al. 2007). Another member of the TGF $\beta$ superfamily, BMP7, increases dendritic length in addition to increasing arborization in hippocampal cultures (Withers et al. 2000). However, unlike these members of the TGF $\beta$ superfamily, TGF $\beta 1$ selectively increases synaptogenesis with no changes in dendritic morphology (Diniz et al. 2012). In addition to its other functions in dendritic density, BDNF mediates spine enlargement and neck shortening at the level of single dendrites in the CA1 region of a hippocampal slice (Tanaka et al. 2008).

\section{GF regulation of dendritic arborization and complexity (outlined in Table $1 C$ )}

BDNF release locally elicits a destabilization of dendrites (Horch et al. 1999) and an increase dendritic arborization (Horch and Katz 2002) in cortical slices. Surprisingly, in hippocampal neurons expressing CAMBP4, which blocks nuclear calcium/CaM signaling, VEGFD, but not other members of the VEGF family (VEGF or VEGFC), rescues the reduction in dendrite length and complex- ity without restoring spine density (Mauceri et al. 2011). Importantly, RNAi depletion of VEGFD in the hippocampus of mice produces a deficit in memory measured in the Morris water maze, but does not affect acquisition of the task. Moreover, impaired contextual fear conditioning, a hippocampus-dependent task, tested at $24 \mathrm{~h}$ is also observed in VEGFD-depleted mice (Mauceri et al. 2011).

At this stage of the review it is important to emphasize two caveats. First, most of the studies reviewed here examine GF regulation of dendritic plasticity in culture, which may not engage the same signaling pathways as those in intact adult circuits. Indeed, BDNF seems to mediate different dendritic changes in cortical neuron culture and in cortical slice (Horch et al. 1999; Horch and Katz 2002; Dijkhuizen and Ghosh 2005). Second, dendritic plasticity is certainly not the only cellular platform upon which long-term memory is dependent. Presynaptic signaling is also critically important and, by extension, GF regulation of presynaptic signaling is certainly another major candidate site for plasticity contributing to memory formation. That said, in restricting our review to a consideration of the wide array of effects on dendritic structure and plasticity mediated by a wide range of GFs, an important emergent principle is that no single form of GF signaling can account for all these effects. Thus GFs must be considered as cooperative and integrative elements in explaining the composite effects on dendritic structure that are thought to be a substrate for learning and memory. This view will critically inform any theory of hippocampal and cortical plasticity thought to underlie the consolidation and storage of LTM.

\section{Spatial and temporal regulation of GF signaling}

It is striking that distinct regulation of different aspects of adult dendritic plasticity is mediated by different GFs, given that GFs engage convergent signaling mechanisms. To begin to understand how these distinct effects are mediated, one must consider: (1) how the regulation of a single canonical signaling molecule might be differentially regulated by different GFs; (2) when during the induction of memory GF signaling is required; and (3) where within a cell and/or brain region GF signaling is engaged during memory formation.

\section{MAPK activation}

The Ras-MEK-MAPK signaling cascade is an evolutionarily conserved pathway that is required for many forms of LTP/LTF and LTM, and is activated by a wide variety of extracellular stimuli, including GF signaling (Adams and Sweatt 2002; Sweatt 2004). Once activated, MAPK can mediate both translation (Kelleher et al. 2004; Tsokas et al. 2007) and transcription (Adams et al. 2000; Davis et al. 2000; Philips et al. 2013). Given the diverse mechanisms upstream of MAPK activation and the diverse outcomes that its activity mediates, MAPK has been postulated to be a critical "node" of plasticity underlying memory formation (Reissner et al. 2006).

MAPK activation is canonically downstream of receptor tyrosine kinase activation triggered by GF binding (Huang and Reichardt 2003; Purcell et al. 2003; Reichardt 2006). TGF $\beta$ superfamily signaling is mediated primarily either by SMAD-dependent pathways (Massague 1998) or MAPK-dependent pathways (Hartsough and Mulder 1995; Shoji-Kasai et al. 2007), although some crosstalk between these pathways has been reported (Yue and Mulder 2000). Interestingly, IGF2 signaling via the IGF2/ M6P receptor, which has no intrinsic kinase activity of its own and is commonly associated with endocytosis and lysosomal targeting (Hille-Rehfeld 1995; Hawkes and Kar 2004), requires MAPK to mediate critical developmental functions (McKinnon et al. 2001). 
MAPK signaling is extremely dynamic, and can be regulated both temporally and spatially in a number of different ways (Adams and Sweatt 2002; Reissner et al. 2006; Kholodenko et al. 2010). For instance, MAPK is activated in different temporal phases, both during and after training, which induces long-term synaptic and behavioral plasticity (Atkins et al. 1998; Sharma et al. 2003; Ajay and Bhalla 2004; Philips et al. 2007; Ye et al. 2008, 2012; Pagani et al. 2009; Shobe et al. 2009; Michel et al. 2011a; Philips et al. 2013). Importantly, each temporal phase can be of critical consequence to LTM induction and maintenance (Atkins et al. 1998; Sharma et al. 2003; Michel et al. 2011a; Ye et al. 2012; Philips et al. 2013).

Intriguingly, GFs can independently activate MAPK with different temporal profiles. Many GFs are capable of rapidly activating MAPK. For instance, in Aplysia sensory neurons, just $5 \mathrm{~min}$ of TGF $\beta 1$ stimulation is sufficient to induce MAPK activation and MEK-dependent phosphorylation of synapsin (Chin et al. 2002). Similarly, TGF $\beta 2$ induces MAPK activation rapidly in epithelial cell culture (by $5 \mathrm{~min}$ ), and increasing incubation time increases MAPK activation maximally at $30 \mathrm{~min}$, which then decreases by $60 \mathrm{~min}$, despite continuous incubation (Hartsough and Mulder 1995). Interestingly, a mix of EGF, insulin, and transferrin also causes sustained MAPK activation in epithelial cell culture, but the maximum level of MAPK activation is at 5 min rather than 30 min (Hartsough and Mulder 1995), suggesting that the mechanism of MAPK activation by GFs may be at least quantitatively different.

Indeed, Zheng and Quirion (2004) found that IGF1 induces both transient MAPK activation and sustained AKT activation, while BDNF induces sustained MAPK activation and transient AKT activation in cultured hippocampal neurons. Additionally, HGF and BDNF, both of which act through receptor tyrosine kinases, have an additive effect on MAPK activation and dendritic growth in rat cortical neurons (Finsterwald and Martin 2011). These data indicate that, even within the receptor tyrosine kinase family of GFs, MAPK (and other signaling molecules) may be differentially regulated. Importantly, different temporal phases of MAPK activation can induce different functional outcomes. For instance, in rat pheochromocytoma (PC12) cells, both forskolin, which increases cAMP levels, and EGF activate MAPK transiently, and neither is sufficient to induce differentiation; however, when applied together, MAPK activation is now sustained, and differentiation is induced (Yao et al. 1995), suggesting that signaling cascades which converge upon MAPK can act synergistically in generating integrated functional outcomes.

Intriguingly, Casar et al. (2009) reported that the subcellular localization of the g-protein Ras is critical in determining substrate specificity downstream of MAPK activation. EGF receptor phosphorylation occurs mainly when MAPK activation arises from lipid rafts, whereas phosphorylation of RSK1, a CREB kinase, occurs mainly when MAPK activation arises from the disordered plasma membrane, a distinction which is governed by different scaffolding proteins (Casar et al. 2009). Indeed, the scaffolding molecule kinase suppressor of ras1 (KSR1) is utilized when MAPK is activated by a PKC-dependent pathway, but not a PKA-dependent pathway, and aids the recruitment of specific downstream targets (Shalin et al. 2006). Importantly, KSR1 is required for LTP and associative learning (Shalin et al. 2006). These data raise the possibility that initiation and modulation of GF signaling cascades, as well as GF-induced MAPK activation itself, may have an as yet unappreciated spatial component of regulation.

In summary, GFs can induce unique temporal phases of MAPK activation. A caveat is warranted, however. It is important to note that exogenous GF application used in many of these studies could, in principle, create an abnormal molecular environment, and natural GF signaling in vivo could exert its effects quite differently.

\section{Temporal regulation of GF signaling during plasticity}

The engagement of GF signaling cascades has long been known to be very tightly regulated in both space and time throughout development in order to create the precise neural circuits necessary for survival (Heerssen and Segal 2002; Dailey et al. 2005; Ramel and Hill 2012). Thus, it is not surprising that there are temporal windows during which GF signaling is required for the induction of LTP/LTF for LTM. For example, IGF2 mRNA and protein is increased in the dorsal hippocampus $20 \mathrm{~h}$, but not 6 or $9 \mathrm{~h}$, after inhibitory avoidance (IA) training in rats (Chen et al. 2011). Furthermore, IGF2 signaling is required for $>1 \mathrm{~d}$, but $<4 \mathrm{~d}$, for the consolidation of IA memory (Chen et al. 2011). NGF has also been shown to be required during a restricted temporal window after training. NGF levels in the CA1 region of the hippocampus increased $1 \mathrm{wk}$, but not earlier or later, after contextual fear conditioning in rats, and antisense knockdown of the NGF receptor TrkA $1 \mathrm{wk}$, but not $4 \mathrm{wk}$, after training impaired freezing behavior at test (Woolf et al. 2001). Interestingly, Ageta et al. (2010) found that blockade of activin signaling specifically impaired late phase of LTP (L-LTP) induced by high-frequency stimulation (HFS). In the presence of an activin antibody or follistatin, a natural activin antagonist, HFS L-LTP was, indeed, induced, but decayed to baseline by $9 \mathrm{~h}$. Further, LTP can be enhanced by exogenous activin application or blocked by activin inhibitors $1 \mathrm{~h}$, but not $3 \mathrm{~h}$, after induction (Ageta et al. 2010).

BDNF signaling and regulation is engaged at very early stages in the neuronal response to activity (Tongiorgi 2008). Surprisingly, recent reports indicate that BDNF is also required in additional phases long after training for a memory to persist (Bekinschtein et al. 2007, 2008). Anti-BDNF antibodies or TrkB-Fc chimera, which sequester endogenous BDNF ligand, administered into the dorsal hippocampus of rats prior to training block the formation of LTM for IA tested at both 2 and 7 d (Bekinschtein et al. 2007, 2008; Chen et al. 2012). Interestingly, protein synthesis inhibitors injected into the dorsal hippocampus $12 \mathrm{~h}$ after IA training block 7-d, but not 2-d, memory (Bekinschtein et al. 2007, 2008), and this effect can be rescued by co-injection of BDNF (Bekinschtein et al. 2008). A similar deficit is observed using anti-BDNF antibody or BDNF antisense oligonucleotides that are injected 10- to 12-h post-training (Bekinschtein et al. 2007), suggesting that BDNF signaling is initially required at early time points during or after IA training for LTM formation, and a translation-dependent event resulting in the release of BDNF (perhaps even translation of BDNF itself) is required $12 \mathrm{~h}$ after training to promote memory persistence out to $7 \mathrm{~d}$. Indeed, BDNF injection into the dorsal hippocampus $12 \mathrm{~h}$ after weak IA training-which alone results in a 2-d, but not 7-d, memory-can promote the expression of LTM at $7 \mathrm{~d}$ (Bekinschtein et al. 2008). Importantly, this facilitation is temporally limited, as BDNF injection $24 \mathrm{~h}$ after weak IA training does not result in memory at $7 \mathrm{~d}$ (Bekinschtein et al. 2008).

As evidence accumulates that specific GFs are required in distinct temporal domains for the induction of lasting plasticity and memory, it will be important to determine not only when GF signaling is required for LTM formation, but how modulation of GF signaling both within and outside of these temporal windows ultimately affects LTM. Whether and how GFs can interact with signaling cascades that have already been activated, including interactive effects between more than one GF, will be important questions to address in future studies.

\section{Spatial regulation of GF signaling during plasticity}

In addition to temporal regulation of GF signaling, GF signaling is also spatially regulated. Although activity-dependent release of GFs occurs at the synapse, GFs also mediate somatic and nuclear 
events. Kanhema et al. (2006) showed that BDNF infusion into the dentate gyrus of anesthetized rats induces LTP and enhanced phosphorylation of eukaryotic initiation factor 4E (eIF4E) and elongation factor-2 (eEF2), which are implicated in enhanced protein synthesis and long-lasting plasticity (Richter and Klann 2009). However, in samples enriched for synapses, BDNF caused a rapid and transient phosphorylation of eIF4E with no effect on eEF2 (Kanhema et al. 2006). These data indicate that BDNF can enhance translation in two different ways (via initiation and via elongation). Initiation is specifically enhanced at the synapse, whereas elongation may be enhanced in the soma or cellwide. Interestingly, regulation of both synaptic initiation and global elongation was MEK-dependent (Kanhema et al. 2006), suggesting BDNF can engage the same signaling mediator (perhaps in different cellular compartments) for spatially segregated outcomes. Chen et al. (2012) also showed that, after IA training, BDNF is capable of regulating the phosphorylation state of a number of proteins at the synapse important for LTM formation, including CAMKII $\alpha$, MAPK, and AKT. Importantly, CREB phosphorylation, which is specifically a nuclear protein, was also modulated by BDNF, indicating that BDNF affects both synaptic and somatic targets.

Additionally, in many cases, a GF binding to its receptor can cause endocytosis of the entire GF-GF receptor complex. This is well documented in the case of retrograde signaling endosomes of NGF and BDNF, where the GF-GF receptor complex travels from the synapse to the soma to regulate nuclear events (Zweifel et al. 2005), EGF-EGF receptor endocytosis (Baulida et al. 1996), and IGF2 clearance via the IGF2 receptor (Lau et al. 1994; Hawkes and Kar 2004). Interestingly, protein kinase C (PKC)-mediated phosphorylation of the EGF receptor can cause it to be sorted into a pool for recycling rather than for degradation (Bao et al. 2000). Since PKC is also implicated as a major player in LTM formation (Olds and Alkon 1993; Serrano et al. 1995; Bonini et al. 2005; Michel et al. 2011b), GF-GF receptor endocytosis and subsequent recycling or degradation, could be a potent regulator of EGF signaling and both spatially and temporally specific plasticity.

GFs have also been reported to preferentially modulate certain cell types. NGF is indispensable for the survival of basal forebrain cholinergic neurons (Van der Zee et al. 1995; Chen et al. 1997; Niewiadomska et al. 2011; Allard et al. 2012). NGF deprivation (by repeated injections of anti-NGF antibodies) in the insular cortex disrupts insular cortex-cholinergic basal forebrain connections, causes a substantial decrease in acetylcholine release following high potassium stimulation, and impairs acquisition of conditioned taste aversion and contextual fear conditioning (Gutierrez et al. 1997). Interestingly, expression of a previously conditioned taste aversion memory (pre-NGF deprivation) is not impaired (Gutierrez et al. 1997), suggesting that cholinergic cells mediate acquisition of memories but are not responsible for storage or expression of memory. Similarly, Conner et al. (2009) found that septal NGF was required for hippocampal LTP and LTM. Interestingly, cholinergic cells are highly susceptible to Alzheimer's disease (AD) pathology (Auld et al. 2002; Mesulam 2004), and NGF has been used as a successful therapy in aged rodents and an AD model (Fischer et al. 1987, 1991; Backman et al. 1996; Frick et al. 1997; Capsoni et al. 2012). NGF effects in young adult rodents is conflicting (Van der Zee et al. 1995; Backman et al. 1996; Muller et al. 2012), indicating that the therapeutic effects of NGF may only be exerted in impaired states (Fischer et al. 1991; Janis et al. 1995; Backman et al. 1996) and may actually impair memory in the absence of pathology (Backman et al. 1996).

Interestingly, FGF is known to be a potent modulator of dopamine neurons (Otto and Unsicker 1993; Mena et al. 1995; Takayama et al. 1995; Grothe and Timmer 2007). It increases dopamine metabolism, striatal F-DOPA uptake, the number of dopamine neurons, and motor function in a nonhuman primate model of Parkinson's disease (Fontan et al. 2002). To our knowledge, the efficacy of FGF to modulate striatal- or dopaminedependent plasticity is not yet understood, though its role in fear memory and extinction is well described (Graham and Richardson 2011).

More than a century of research examining brain-behavior relationships in the general context of learning and memory has clearly revealed that memory for different learning tasks can be processed in different brain regions. After training, an IGF2 injection is capable of enhancing IA memory if injected into the hippocampus, but not the amygdala (Chen et al. 2011), suggesting that although both the hippocampus and amygdala are important for IA memory, IGF2 is selectively recruited by the hippocampus in this task. BDNF is an important regulator of hippocampal plasticity and hippocampus-dependent memory, but can also modulate amygdala-dependent plasticity (Rattiner et al. 2004, 2005; Meis et al. 2012). Indeed, BDNF signaling is required for LTP induced in thalamus-amygdala connections, but is not required for LTP induced at cortex-amygdala connections (Meis et al. 2012), suggesting that BDNF may have varied, but restricted, roles in different brain regions. Interestingly, in an object recognition task, BDNF release is increased following training and after 24-h testing in both the dentate gyrus and perirhinal cortex (Callaghan and Kelly 2012). In the dentate gyrus, BDNF release is correlated with an increase in MAPK phosphorylation and c-fos induction after training, but not after testing. In the perirhinal cortex, BDNF release is correlated with c-fos induction after training with no discernible modulation of MAPK phosphorylation (Callaghan and Kelly 2012). These data suggest that spatially segregated BDNF signaling may engage different mechanisms over time during the consolidation of a single object recognition memory.

\section{GF signaling: a molecular network}

Taking into account the unique functional outcomes and the distinct mechanistic, temporal, and spatial regulation of GF signaling, it is important to consider how different GF signaling cascades cooperate and interact to modulate plasticity. For instance, in COS-7 cells, IGF1 stimulation engages the canonical IGF1 signaling cascade as well as induces the transactivation of EGF receptor, which then activates its canonical signaling cascade (Roudabush et al. 2000), suggesting that some GFs may be able to induce other GF signaling cascades by ligand-independent intracellular mechanisms. Furthermore, GFs can also stimulate the expression of other GFs. IGF1 administration after experimentally induced brain trauma not only stabilizes BDNF and NT3 levels (which decrease in certain areas after trauma), but enhances those levels (Kazanis et al. 2004). Similarly, IGF1 receptor signaling is required for the up-regulation of BDNF mRNA and protein in response to exercise (Ding et al. 2006).

In developing basal forebrain neuron culture, BMP9 increases NGF protein expression and secretion, which in turn increases acetylcholine production (Schnitzler et al. 2010). Similarly, in embryonic cutaneous cells, stimulation with TGF $\beta 1,2$, or 3 induces a biphasic induction of NGF mRNA: (1) an abrupt, early rise that decays after $2 \mathrm{~h}$ and (2) a more gradual increase from 12 to $48 \mathrm{~h}$ (Buchman et al. 1994). Interestingly, although all TGF $\beta$ isoforms show this profile, TGF $\beta 1$ induces the largest increase in NGF mRNA during the first phase, while TGF 32 induces the largest increase in NGF mRNA during the second phase (Buchman et al. 1994), suggesting a difference in mechanism or efficiency of TGF $\beta$ signaling at different time points.

Some GFs actually require other GF signaling cascades for their own functional outcomes. For instance, the neuroprotective effect of basic FGF after acute excitotoxic brain injury induced by 
kainic acid in the CA3 region of the hippocampus requires the induction of activin A (Tretter et al. 2000). Additionally, Dennis and Rifkin (1991) reported that migration inhibition by TGF $\beta$ in wound cultures of bovine aortic endothelial cell culture requires latent TGF $\beta$ to bind to IGF2/M6P receptor, which induces its conversion to the mature, active form of TGF $\beta$. Indeed, a mannose 6phosphate domain is found in the latent version of TGF $\beta 1$ (Purchio et al. 1988), suggesting that IGF2 receptor may be a limiting factor in the conversion and subsequent action of TGF $\beta$. Whether IGF2 receptor is required for the functional actions or signaling engagement of TGF $\beta$ in adult plasticity remains to be elucidated.

\section{Conclusion}

It is now widely appreciated that GFs are critical regulators of both developmental and adult plasticity. What remains to be elucidated is how specific GFs exert their effects to form long-lasting behavioral and structural plasticity. We have reviewed data indicating that GF signaling is dynamically regulated in both space and time during learning and memory formation. Furthermore, it is now clear that focusing on a single GF is not sufficient to account for all the structural changes that occur at dendrites during experience-dependent plasticity. Rather, GFs should be considered as elements within an interactive network.

Underscoring the importance of the notion of GF networks is the fact that, because of their secretion and extracellular ligandreceptor binding domains, GFs are potentially powerful therapeutic targets for many neurological diseases and disorders. If individual GFs mediate only a subset of the molecular requirements for the induction of learning and memory, then a therapeutic system based on a single GF may not be sufficient to rescue learning and memory deficits. One must consider (1) the effect of a more global delivery of several GFs or GF agonists in specific therapies, (2) the time at which GF is delivered, and (3) whether the GF will antagonize or enhance other GF signaling pathways. For instance, in the CA1 region of the hippocampus, the number of neurons expressing high levels of BDNF increases by only $\sim 2 \% 24 \mathrm{~h}$ after contextual fear conditioning (Chen et al. 2007). A global increase in BDNF could, in principle, cause more harm than good. Indeed, overexpression of BDNF has been reported to increase anxiety-like behavior, seizure activity, and impair some forms of memory (Croll et al. 1999; Govindarajan et al. 2006; Cunha et al. 2009; Papaleo et al. 2011).

In conclusion, the central theme of this review is that GF signaling in long-lasting behavioral, cellular, and structural plasticity is best viewed as temporally and spatially regulated within a complex molecular network. While there are certainly additional challenges presented by this view, as it adds to the overall complexity of the problem, there are benefits as well. From a basic scientific perspective it can open new avenues for productive inquiry, and from a clinically relevant perspective, it can, in principle, suggest novel approaches to therapies addressing cognitive impairments that accompany a wide range of neurological disorders.

\section{Acknowledgments}

We thank Gary T. Philips for thoughtful comments on an earlier version of this work. This work was supported by NIMH R01MH041083 and R01MH094792 to T.J.C.

\section{References}

Abe K, Xie FJ, Saito H. 1991. Epidermal growth-factor enhances short-term potentiation and facilitates induction of long-term potentiation in rat hippocampal slices. Brain Res 547: 171-174.
Acebes A, Morales M. 2012. At a PI3K crossroads: Lessons from flies and rodents. Rev Neurosci 23: 29-37.

Adams JP, Sweatt JD. 2002. Molecular psychology: Roles for the ERK MAP kinase cascade in memory. Annu Rev Pharmacol Toxicol 42: 135-163.

Adams JP, Roberson ED, English JD, Selcher JC, Sweatt JD. 2000. MAPK regulation of gene expression in the central nervous system. Acta Neurobiol Exp (Wars) 60: 377-394.

Ageta H, Ikegami S, Miura M, Masuda M, Migishima R, Hino T, Takashima N, Murayama A, Sugino H, Setou M, et al. 2010. Activin plays a key role in the maintenance of long-term memory and late-LTP. Learn Mem 17: 176-185.

Ajay SM, Bhalla US. 2004. A role for ERKII in synaptic selectivity on the time-scale of minutes. Eur J Neurosci 20: 2671-2680.

Alberini CM. 2009. Transcription factors in long-term memory and synaptic plasticity. Physiol Rev 89: 121-145.

Allard S, Leon WC, Pakavathkumar P, Bruno MA, Ribeiro-da-Silva A, Cuello AC. 2012. Impact of the NGF maturation and degradation pathway on the cortical cholinergic system phenotype. J Neurosci 32: 2002-2012.

Atkins CM, Selcher JC, Petraitis JJ, Trzaskos JM, Sweatt JD. 1998. The MAPK cascade is required for mammalian associative learning. Nat Neurosci 1: 602-609.

Auld DS, Kornecook TJ, Bastianetto S, Quirion R. 2002. Alzheimer's disease and the basal forebrain cholinergic system: Relations to $\beta$-amyloid peptides, cognition, and treatment strategies. Prog Neurobiol 68: 209-245.

Backman C, Rose GM, Hoffer BJ, Henry MA, Bartus RT, Friden P, Granholm AC. 1996. Systemic administration of a nerve growth factor conjugate reverses age-related cognitive dysfunction and prevents cholinergic neuron atrophy. J Neurosci 16: 5437-5442.

Bailey CH, Kandel ER. 1993. Structural changes accompanying memory storage. Annu Rev Physiol 55: 397-426.

Bailey CH, Kandel ER. 2008. Synaptic remodeling, synaptic growth and the storage of long-term memory in Aplysia. Prog Brain Res 169: 179-198.

Bailey CH, Bartsch D, Kandel ER. 1996. Toward a molecular definition of long-term memory storage. Proc Natl Acad Sci 93: 13445-13452.

Bao J, Alroy I, Waterman H, Schejter ED, Brodie C, Gruenberg J, Yarden Y. 2000. Threonine phosphorylation diverts internalized epidermal growth factor receptors from a degradative pathway to the recycling endosome. J Biol Chem 275: 26178-26186.

Baulida J, Kraus MH, Alimandi M, DiFiore PP, Carpenter G. 1996. All ErbB receptors other than the epidermal growth factor receptor are endocytosis impaired. J Biol Chem 271: 5251-5257.

Bekinschtein P, Cammarota M, Igaz LM, Bevilaqua LR, Izquierdo I, Medina JH. 2007. Persistence of long-term memory storage requires a late protein synthesis- and BDNF-dependent phase in the hippocampus. Neuron 53: 261-277.

Bekinschtein P, Cammarota M, Katche C, Slipczuk L, Rossato JI, Goldin A Izquierdo I, Medina JH. 2008. BDNF is essential to promote persistence of long-term memory storage. Proc Natl Acad Sci 105: 2711-2716.

Bonini JS, Cammarota M, Kerr DS, Bevilaqua LR, Izquierdo I. 2005. Inhibition of PKC in basolateral amygdala and posterior parietal cortex impairs consolidation of inhibitory avoidance memory. Pharmacol Biochem Behav 80: 63-67.

Bourtchuladze R, Frenguelli B, Blendy J, Cioffi D, Schutz G, Silva AJ. 1994 Deficient long-term memory in mice with a targeted mutation of the cAMP-responsive element-binding protein. Cell 79: 59-68.

Buchman VL, Sporn M, Davies AM. 1994. Role of transforming growth-factor- $\beta$ isoforms in regulating the expression of nerve growth-factor and neurotrophin-3 messenger-RNA levels in embryonic cutaneous cells at different stages of development. Development 120: $1621-1629$.

Callaghan CK, Kelly AM. 2012. Differential BDNF signaling in dentate gyrus and perirhinal cortex during consolidation of recognition memory in the rat. Hippocampus 22: 2127-2135.

Capsoni S, Marinelli S, Ceci M, Vignone D, Amato G, Malerba F, Paoletti F, Meli G, Viegi A, Pavone FA, et al. 2012. Intranasal "painless" human nerve growth factor slows amyloid neurodegeneration and prevents memory deficits in App X PS1 mice. PLoS One 7: e37555.

Caroni P, Donato F, Muller D. 2012. Structural plasticity upon learning: Regulation and functions. Nat Neurosci 13: 478-490.

Casar B, Arozarena I, Sanz-Moreno V, Pinto A, Agudo-Ibanez L, Marais R, Lewis RE, Berciano MT, Crespo P. 2009. Ras subcellular localization defines extracellular signal-regulated kinase 1 and 2 substrate specificity through distinct utilization of scaffold proteins. Mol Cell Biol 29: $1338-1353$.

Castellucci VF, Blumenfeld H, Goelet P, Kandel ER. 1989. Inhibitor of protein synthesis blocks long-term behavioral sensitization in the isolated gill-withdrawal reflex of Aplysia. J Neurobiol 20: 1-9.

Chen KS, Nishimura MC, Armanini MP, Crowley C, Spencer SD, Phillips HS. 1997. Disruption of a single allele of the nerve growth 
factor gene results in atrophy of basal forebrain cholinergic neurons and memory deficits. J Neurosci 17: 7288-7296.

Chen J, Kitanishi T, Ikeda T, Matsuki N, Yamada MK. 2007. Contextual learning induces an increase in the number of hippocampal CA1 neurons expressing high levels of BDNF. Neurobiol Learn Mem 88: $409-415$.

Chen DY, Stern SA, Garcia-Osta A, Saunier-Rebori B, Pollonini G, Bambah-Mukku D, Blitzer RD, Alberini CM. 2011. A critical role for IGF-II in memory consolidation and enhancement. Nature 469: 491-497.

Chen DY, Bambah-Mukku D, Pollonini G, Alberini CM. 2012. Glucocorticoid receptors recruit the CaMKII $\alpha$-BDNF-CREB pathways to mediate memory consolidation. Nat Neurosci 15: 1707-1716.

Chin J, Angers A, Cleary LJ, Eskin A, Byrne JH. 2002. Transforming growth factor $\beta 1$ alters synapsin distribution and modulates synaptic depression in Aplysia. J Neurosci 22: RC220.

Chiu SL, Chen CM, Cline HT. 2008. Insulin receptor signaling regulates synapse number, dendritic plasticity, and circuit function in vivo. Neuron 58: 708-719.

Cohen S, Levi-Montalcini R, Hamburger V. 1954. A nerve growth-stimulating factor isolated from sarcomas 37 and 180. Proc Natl Acad Sci 40: 1014-1018.

Conner JM, Franks KM, Titterness AK, Russell K, Merrill DA, Christie BR, Sejnowski TJ, Tuszynski MH. 2009. NGF is essential for hippocampal plasticity and learning. J Neurosci 29: 10883-10889.

Croll SD, Suri C, Compton DL, Simmons MV, Yancopoulos GD, Lindsay RM, Wiegand SJ, Rudge JS, Scharfman HE. 1999. Brain-derived neurotrophic factor transgenic mice exhibit passive avoidance deficits, increased seizure severity and in vitro hyperexcitability in the hippocampus and entorhinal cortex. Neuroscience 93: 1491-1506.

Cunha C, Angelucci A, D'Antoni A, Dobrossy MD, Dunnett SB, Berardi N, Brambilla R. 2009. Brain-derived neurotrophic factor (BDNF) overexpression in the forebrain results in learning and memory impairments. Neurobiol Dis 33: 358-368.

Dailey L, Ambrosetti D, Mansukhani A, Basilico C. 2005. Mechanisms underlying differential responses to FGF signaling. Cytokine Growth Factor Rev 16: 233-247.

Davis S, Vanhoutte P, Pages C, Caboche J, Laroche S. 2000. The MAPK/ERK cascade targets both Elk-1 and cAMP response element-binding protein to control long-term potentiation-dependent gene expression in the dentate gyrus in vivo. J Neurosci 20: 4563-4572.

De Almodovar CR, Lambrechts D, Mazzone M, Carmeliet P. 2009. Role and therapeutic potential of VEGF in the nervous system. Physiol Rev 89: 607-648.

Dennis PA, Rifkin DB. 1991. Cellular activation of latent transforming growth-factor- $\beta$ requires binding to the cation-independent mannose 6-phosphate insulin-like growth-factor type-II receptor. Proc Natl Acad Sci 88: $580-584$.

Dijkhuizen PA, Ghosh A. 2005. BDNF regulates primary dendrite formation in cortical neurons via the PI3-kinase and MAP kinase signaling pathways. J Neurobiol 62: 278-288.

Ding Q, Vaynman S, Akhavan M, Ying Z, Gomez-Pinilla F. 2006. Insulin-like growth factor I interfaces with brain-derived neurotrophic factor-mediated synaptic plasticity to modulate aspects of exercise-induced cognitive function. Neuroscience 140: 823-833.

Diniz LP, Almeida JC, Tortelli V, Lopes CV, Setti-Perdigao P, Stipursky J, Kahn SA, Romao LF, de Miranda J, Alves-Leon SV, et al. 2012. Astrocyte-induced synaptogenesis is mediated by transforming growth factor $\beta$ signaling through modulation of D-serine levels in cerebral cortex neurons. J Biol Chem 287: 41432-41445.

Egan MF, Kojima M, Callicott JH, Goldberg TE, Kolachana BS, Bertolino A, Zaitsev E, Gold B, Goldman D, Dean M, et al. 2003. The BDNF val66met polymorphism affects activity-dependent secretion of BDNF and human memory and hippocampal function. Cell 112: 257-269.

Finkbeiner S, Tavazoie SF, Maloratsky A, Jacobs KM, Harris KM, Greenberg ME. 1997. CREB: A major mediator of neuronal neurotrophin responses. Neuron 19: 1031-1047.

Finsterwald C, Martin JL. 2011. Cellular mechanisms underlying the regulation of dendritic development by hepatocyte growth factor. Eur J Neurosci 34: 1053-1061.

Fischer W, Wictorin K, Bjorklund A, Williams LR, Varon S, Gage FH. 1987. Amelioration of cholinergic neuron atrophy and spatial memory impairment in aged rats by nerve growth factor. Nature 329: 65-68

Fischer W, Bjorklund A, Chen K, Gage FH. 1991. NGF improves spatial memory in aged rodents as a function of age. J Neurosci 11: 1889-1906.

Fontan A, Rojo A, Pernaute RS, Hernandez I, Lopez I, Castilla C, Albisua JS, Higueras AP, Al-Rashid I, Rabano A, et al. 2002. Effects of fibroblast growth factor and glial-derived neurotrophic factor on akinesia, F-DOPA uptake and dopamine cells in Parkinsonian primates. Parkinsonism Relat Disord 8: 311-323.
Frankland PW, Bontempi B. 2005. The organization of recent and remote memories. Nat Rev Neurosci 6: 119-130.

Frick KM, Price DL, Koliatsos VE, Markowska AL. 1997. The effects of nerve growth factor on spatial recent memory in aged rats persist after discontinuation of treatment. J Neurosci 17: 2543-2550.

Govindarajan A, Rao BS, Nair D, Trinh M, Mawjee N, Tonegawa S, Chattarji S. 2006. Transgenic brain-derived neurotrophic factor expression causes both anxiogenic and antidepressant effects. Proc Natl Acad Sci 103: 13208-13213.

Graham BM, Richardson R. 2011. Memory of fearful events: the role of fibroblast growth factor-2 in fear acquisition and extinction. Neuroscience 189: 156-169.

Grothe C, Timmer M. 2007. The physiological and pharmacological role of basic fibroblast growth factor in the dopaminergic nigrostriatal system. Brain Res Rev 54: 80-91.

Gutierrez H, Miranda MI, Bermudez-Rattoni F. 1997. Learning impairment and cholinergic deafferentation after cortical nerve growth factor deprivation. J Neurosci 17: 3796-3803.

Hartsough MT, Mulder KM. 1995. Transforming growth-factor- $\beta$ activation of P44 ${ }^{\text {mapk }}$ in proliferating cultures of epithelial-cells. J Biol Chem 270: 7117-7124.

Hawkes C, Kar S. 2004. The insulin-like growth factor-II/ mannose-6-phosphate receptor: Structure, distribution and function in the central nervous system. Brain Res Brain Res Rev 44: 117-140.

Heerssen HM, Segal RA. 2002. Location, location, location: A spatial view of neurotrophin signal transduction. Trends Neurosci 25: $160-165$.

Hille-Rehfeld A. 1995. Mannose 6-phosphate receptors in sorting and transport of lysosomal enzymes. Biochim Biophys Acta 1241: $177-194$.

Hoch RV, Soriano P. 2003. Roles of PDGF in animal development. Development 130: 4769-4784.

Hofer SB, Mrsic-Flogel TD, Bonhoeffer T, Hubener M. 2009. Experience leaves a lasting structural trace in cortical circuits. Nature 457: 313-317.

Horch HW, Katz LC. 2002. BDNF release from single cells elicits local dendritic growth in nearby neurons. Nat Neurosci 5: 1177-1184.

Horch HW, Kruttgen A, Portbury SD, Katz LC. 1999. Destabilization of cortical dendrites and spines by BDNF. Neuron 23: 353-364.

Horwood JM, Dufour F, Laroche S, Davis S. 2006. Signalling mechanisms mediated by the phosphoinositide 3-kinase/Akt cascade in synaptic plasticity and memory in the rat. Eur J Neurosci 23: 3375-3384.

Huang EJ, Reichardt LF. 2003. Trk receptors: Roles in neuronal signal transduction. Annu Rev Biochem 72: 609-642.

Ishiyama J, Saito H, Abe K. 1991. Epidermal growth-factor and basic fibroblast growth-factor promote the generation of long-term potentiation in the dentate gyrus of anesthetized rats. Neurosci Res 12: $403-411$.

Janis LS, Glasier MM, Martin G, Stackman RW, Walsh TJ, Stein DG. 1995. A single intraseptal injection of nerve growth factor facilitates radial maze performance following damage to the medial septum in rats. Brain Res 679: $99-109$.

Ji Y, Pang PT, Feng L, Lu B. 2005. Cyclic AMP controls BDNF-induced TrkB phosphorylation and dendritic spine formation in mature hippocampal neurons. Nat Neurosci 8: 164-172.

Kanhema T, Dagestad G, Panja D, Tiron A, Messaoudi E, Havik B, Ying SW, Nairn AC, Sonenberg N, Bramham CR. 2006. Dual regulation of translation initiation and peptide chain elongation during BDNF-induced LTP in vivo: Evidence for compartment-specific translation control. J Neurochem 99: 1328-1337.

Kato T, Funakoshi H, Kadoyama K, Noma S, Kanai M, Ohya-Shimada W, Mizuno S, Doe N, Taniguchi T, Nakamura T. 2012. Hepatocyte growth factor overexpression in the nervous system enhances learning and memory performance in mice. J Neurosci Res 90: 1743-1755.

Kazanis I, Giannakopoulou M, Philippidis H, Stylianopoulou F. 2004. Alterations in IGF-I, BDNF and NT-3 levels following experimental brain trauma and the effect of IGF-I administration. Exp Neurol 186: 221-234.

Kelleher RJ 3rd, Govindarajan A, Jung HY, Kang H, Tonegawa S. 2004. Translational control by MAPK signaling in long-term synaptic plasticity and memory. Cell 116: 467-1479.

Kholodenko BN, Hancock JF, Kolch W. 2010. Signalling ballet in space and time. Nat Rev Mol Cell Biol 11: 414-426.

Knafo S, Grossman Y, Barkai E, Benshalom G. 2001. Olfactory learning is associated with increased spine density along apical dendrites of pyramidal neurons in the rat piriform cortex. Eur J Neurosci 13: 633-638.

Krieglstein K, Zheng F, Unsicker K, Alzheimer C. 2011. More than being protective: Functional roles for TGF- $\beta$ /activin signaling pathways at central synapses. Trends Neurosci 34: 421-429.

Lamprecht R, LeDoux J. 2004. Structural plasticity and memory. Nat Rev Neurosci 5: 45-54. 
Lau MM, Stewart CE, Liu Z, Bhatt H, Rotwein P, Stewart CL. 1994. Loss of the imprinted IGF2/cation-independent mannose 6-phosphate receptor results in fetal overgrowth and perinatal lethality. Genes Dev 8: $2953-2963$.

Lee KJ, Jung JG, Arii T, Imoto K, Rhyu IJ. 2007. Morphological changes in dendritic spines of Purkinje cells associated with motor learning. Neurobiol Learn Mem 88: 445-450.

Lee YS, Bailey CH, Kandel ER, Kaang BK. 2008. Transcriptional regulation of long-term memory in the marine snail Aplysia. Mol Brain 1: 3.

Levi-Montalcini R, Skaper SD, Dal Toso R, Petrelli L, Leon A. 1996. Nerve growth factor: From neurotrophin to neurokine. Trends Neurosci 19: $514-520$.

Lin CH, Yeh SH, Lin CH, Lu KT, Leu TH, Chang WC, Gean PW. 2001. A role for the PI-3 kinase signaling pathway in fear conditioning and synaptic plasticity in the amygdala. Neuron 31: 841-851.

Martin KC, Michael D, Rose JC, Barad M, Casadio A, Zhu H, Kandel ER. 1997. MAP kinase translocates into the nucleus of the presynaptic cell and is required for long-term facilitation in Aplysia. Neuron 18: $899-912$.

Massague J. 1998. TGF- $\beta$ signal transduction. Annu Rev Biochem 67: $753-791$.

Massague J. 2000. How cells read TGF- $\beta$ signals. Nat Rev Mol Cell Biol 1: $169-178$

Mauceri D, Freitag HE, Oliveira AMM, Bengtson CP, Bading H. 2011. Nuclear calcium-VEGFD signaling controls maintenance of dendrite arborization necessary for memory formation. Neuron 71: 117-130.

McKinnon T, Chakraborty C, Gleeson LM, Chidiac P, Lala PK. 2001. Stimulation of human extravillous trophoblast migration by IGF-II is mediated by IGF type 2 receptor involving inhibitory G protein(s) and phosphorylation of MAPK. J Clin Endocrinol Metab 86: 3665-3674.

McNay EC, Ong CT, McCrimmon RJ, Cresswell J, Bogan JS,

Sherwin RS. 2010. Hippocampal memory processes are modulated by insulin and high-fat-induced insulin resistance. Neurobiol Learn Mem 93: $546-553$.

Meis S, Endres T, Lessmann V. 2012. Postsynaptic BDNF signalling regulates long-term potentiation at thalamo-amygdala afferents. J Physiol 590: $193-208$.

Mena MA, Casarejos MJ, Gimenez-Gallego G, Garcia de Yebenes J. 1995. Fibroblast growth factors: Structure-activity on dopamine neurons in vitro. J Neural Transm Park Dis Dement Sect 9: 1-14.

Mesulam M. 2004. The cholinergic lesion of Alzheimer's disease: Pivotal factor or side show? Learn Mem 11: 43-49.

Michel M, Green CL, Eskin A, Lyons LC. 2011a. PKG-mediated MAPK signaling is necessary for long-term operant memory in Aplysia. Learn Mem 18: $108-117$.

Michel M, Green CL, Lyons LC. 2011b. PKA and PKC are required for long-term but not short-term in vivo operant memory in Aplysia. Learn Mem 18: 19-23.

Muller M, Triaca V, Besusso D, Costanzi M, Horn JM, Koudelka J, Geibel M, Cestari V, Minichiello L. 2012. Loss of NGF-TrkA signaling from the CNS is not sufficient to induce cognitive impairments in young adult or intermediate-aged mice. J Neurosci 32: 14885-14898.

Nakamura T, Sakai K, Nakamura T, Matsumoto K. 2011. Hepatocyte growth factor twenty years on: Much more than a growth factor. J Gastroenterol Hepatol 26: 188-202.

Niewiadomska G, Mietelska-Porowska A, Mazurkiewicz M. 2011. The cholinergic system, nerve growth factor and the cytoskeleton. Behav Brain Res 221: 515-526.

Olds JL, Alkon DL. 1993. Protein kinase C: A nexus in the biochemical events that underlie associative learning. Acta Neurobiol Exp (Wars) 53: $197-207$.

Opazo P, Watabe AM, Grant SG, O'Dell TJ. 2003. Phosphatidylinositol 3-kinase regulates the induction of long-term potentiation through extracellular signal-related kinase-independent mechanisms. J Neurosci 23: 3679-3688.

Otto D, Unsicker K. 1993. FGF-2 modulates dopamine and dopamine-related striatal transmitter systems in the intact and MPTP-lesioned mouse. Eur J Neurosci 5: 927-932.

Pagani MR, Oishi K, Gelb BD, Zhong Y. 2009. The phosphatase SHP2 regulates the spacing effect for long-term memory induction. Cell 139: $186-198$.

Papaleo F, Silverman JL, Aney J, Tian Q, Barkan CL, Chadman KK, Crawley JN. 2011. Working memory deficits, increased anxiety-like traits, and seizure susceptibility in BDNF overexpressing mice. Learn Mem 18: 534-544.

Park H, Poo MM. 2013. Neurotrophin regulation of neural circuit development and function. Nat Rev Neurosci 14: 7-23.

Park CR, Seeley RJ, Craft S, Woods SC. 2000. Intracerebroventricular insulin enhances memory in a passive-avoidance task. Physiol Behav 68: 509-514.

Peng FW, Yao HH, Bai XT, Zhu XH, Reiner BC, Beazely M, Funa K, Xiong HG, Buch S. 2010. Platelet-derived growth factor-mediated induction of the synaptic plasticity gene arc/arg3.1. J Biol Chem 285: $21615-21624$.

Philips GT, Tzvetkova EI, Carew TJ. 2007. Transient mitogen-activated protein kinase activation is confined to a narrow temporal window required for the induction of two-trial long-term memory in Aplysia. J Neurosci 27: 13701-13705.

Philips GT, Ye X, Kopec AM, Carew TJ. 2013. MAPK establishes a molecular context that defines effective training patterns for long-term memory formation. J Neurosci. 33: 7565-7573.

Prenzel N, Fischer OM, Streit S, Hart S, Ullrich A. 2001. The epidermal growth factor receptor family as a central element for cellular signal transduction and diversification. Endocr Relat Cancer 8: 11-31.

Purcell AL, Sharma SK, Bagnall MW, Sutton MA, Carew TJ. 2003. Activation of a tyrosine kinase-MAPK cascade enhances the induction of long-term synaptic facilitation and long-term memory in Aplysia. Neuron 37: 473-484.

Purchio AF, Cooper JA, Brunner AM, Lioubin MN, Gentry LE, Kovacina KS, Roth RA, Marquardt H. 1988. Identification of mannose 6-phosphate in 2 asparagine-linked sugar chains of recombinant transforming growth factor- $\beta-1$ precursor. J Biol Chem 263: 14211-14215.

Ramel MC, Hill CS. 2012. Spatial regulation of BMP activity. FEBS Lett 586: $1929-1941$.

Rattiner LM, Davis M, French CT, Ressler KJ. 2004. Brain-derived neurotrophic factor and tyrosine kinase receptor B involvement in amygdala-dependent fear conditioning. J Neurosci 24: $4796-4806$.

Rattiner LM, Davis M, Ressler KJ. 2005. Brain-derived neurotrophic factor in amygdala-dependent learning. Neuroscientist 11: 323-333.

Reichardt LF. 2006. Neurotrophin-regulated signalling pathways. Philos Trans R Soc Lond B Biol Sci 361: 1545-1564.

Reissner KJ, Shobe JL, Carew TJ. 2006. Molecular nodes in memory processing: Insights from Aplysia. Cell Moll Life Sci 63: 963-974.

Restivo L, Vetere G, Bontempi B, Ammassari-Teule M. 2009. The formation of recent and remote memory is associated with time-dependent formation of dendritic spines in the hippocampus and anterior cingulate cortex. J Neurosci 29: 8206-8214.

Richter JD, Klann E. 2009. Making synaptic plasticity and memory last: Mechanisms of translational regulation. Genes Dev 23: 1-11.

Roberts TF, Tschida KA, Klein ME, Mooney R. 2010. Rapid spine stabilization and synaptic enhancement at the onset of behavioural learning. Nature 463: 948-952.

Roudabush FL, Pierce KL, Maudsley S, Khan KD, Luttrell LM. 2000. Transactivation of the EGF receptor mediates IGF-1-stimulated Shc phosphorylation and ERK1/2 activation in COS-7 cells. J Biol Chem 275: 22583-22589.

Sangha S, Scheibenstock A, McComb C, Lukowiak K. 2003. Intermediate and long-term memories of associative learning are differentially affected by transcription versus translation blockers in Lymnaea. J Exp Biol 206: 1605-1613.

Schmeisser MJ, Baumann B, Johannsen S, Vindedal GF, Jensen V, Hvalby OC, Sprengel R, Seither J, Maqbool A, Magnutzki A, et al. 2012. I $\kappa$ B kinase/nuclear factor $\kappa$ B-dependent insulin-like growth factor 2 (IGF2) expression regulates synapse formation and spine maturation via IGF2 receptor signaling. J Neurosci 32: 5688-5703.

Schnitzler AC, Mellott TJ, Lopez-Coviella I, Tallini YN, Kotlikoff MI, Follettie MT, Blusztajn JK. 2010. BMP9 (bone morphogenetic protein 9) induces NGF as an autocrine/paracrine cholinergic trophic factor in developing basal forebrain neurons. J Neurosci 30: 8221-8228.

Segal M. 2005. Dendritic spines and long-term plasticity. Nat Rev Neurosci 6: $277-284$

Serrano PA, Rodriguez WA, Pope B, Bennett EL, Rosenzweig MR. 1995. Protein kinase $\mathrm{C}$ inhibitor chelerythrine disrupts memory formation in chicks. Behav Neurosci 109: 278-284.

Shalin SC, Hernandez CM, Dougherty MK, Morrison DK, Sweatt JD. 2006. Kinase suppressor of Ras1 compartmentalizes hippocampal signal transduction and subserves synaptic plasticity and memory formation. Neuron 50: 765-779.

Sharma SK, Sherff CM, Shobe JL, Bagnall MW, Sutton MA, Carew TJ. 2003. Differential role of mitogen-activated protein kinase in three distinct phases of memory for sensitization in Aplysia. J Neurosci 23: 3899-3907.

Sharma SK, Sherff CM, Stough S, Hsuan V, Carew TJ. 2006. A tropomyosin-related kinase B ligand is required for ERK activation, long-term synaptic facilitation, and long-term memory in Aplysia. Proc Natl Acad Sci 103: 14206-14210.

Shioda N, Moriguchi S, Oya T, Ishii Y, Shen J, Matsushima T, Nishijo H, Sasahara M, Fukunaga K. 2012. Aberrant hippocampal spine morphology and impaired memory formation in neuronal platelet-derived growth factor $\beta$-receptor lacking mice. Hippocampus 22: $1371-1378$

Shobe JL, Zhao Y, Stough S, Ye X, Hsuan V, Martin KC, Carew TJ. 2009. Temporal phases of activity-dependent plasticity and memory are 
mediated by compartmentalized routing of MAPK signaling in Aplysia sensory neurons. Neuron 61: 113-125.

Shoji-Kasai Y, Ageta H, Hasegawa Y, Tsuchida K, Sugino H, Inokuchi K. 2007. Activin increases the number of synaptic contacts and the length of dendritic spine necks by modulating spinal actin dynamics. J Cell Sci Suppl 120: 3830-3837.

Stough S, Shobe JL, Carew TJ. 2006. Intermediate-term processes in memory formation. Curr Opin Neurobiol 16: 672-678.

Sui L, Wang J, Li BM. 2008. Role of the phosphoinositide 3-kinase-Akt-mammalian target of the rapamycin signaling pathway in long-term potentiation and trace fear conditioning memory in rat medial prefrontal cortex. Learn Mem 15: 762-776.

Sutton MA, Masters SE, Bagnall MW, Carew TJ. 2001. Molecular mechanisms underlying a unique intermediate phase of memory in Aplysia. Neuron 31: 143-154.

Sweatt JD. 2004. Mitogen-activated protein kinases in synaptic plasticity and memory. Curr Opin Neurobiol 14: 311-317.

Takayama H, Ray J, Raymon HK, Baird A, Hogg J, Fisher LJ, Gage FH. 1995. Basic fibroblast growth factor increases dopaminergic graft survival and function in a rat model of Parkinson's disease. Nat Med 1: 53-58.

Tanaka J, Horiike Y, Matsuzaki M, Miyazaki T, Ellis-Davies GC, Kasai H. 2008. Protein synthesis and neurotrophin-dependent structural plasticity of single dendritic spines. Science 319: 1683-1687.

Taniguchi CM, Emanuelli B, Kahn CR. 2006. Critical nodes in signalling pathways: Insights into insulin action. Nat Rev Mol Cell Biol 7: 85-96.

Tongiorgi E. 2008. Activity-dependent expression of brain-derived neurotrophic factor in dendrites: Facts and open questions. Neurosci Res 61: $335-346$.

Tretter YP, Hertel M, Munz B, ten Bruggencate G, Werner S, Alzheimer C. 2000. Induction of activin A is essential for the neuroprotective action of basic fibroblast growth factor in vivo. Nat Med 6: 812-815.

Tsokas P, Ma T, Iyengar R, Landau EM, Blitzer RD. 2007. Mitogen-activated protein kinase upregulates the dendritic translation machinery in long-term potentiation by controlling the mammalian target of rapamycin pathway. J Neurosci 27: 5885-5894.

Turner CA, Akil H, Watson SJ, Evans SJ. 2006. The fibroblast growth factor system and mood disorders. Biol Psychiatry 59: 1128-1135.

Van der Zee CE, Lourenssen S, Stanisz J, Diamond J. 1995. NGF deprivation of adult rat brain results in cholinergic hypofunction and selective impairments in spatial learning. Eur J Neurosci 7: 160-168.

Withers GS, Higgins D, Charette M, Banker G. 2000. Bone morphogenetic protein-7 enhances dendritic growth and receptivity to innervation in cultured hippocampal neurons. Eur J Neurosci 12: 106-116.

Won J, Silva AJ. 2008. Molecular and cellular mechanisms of memory allocation in neuronetworks. Neurobiol Learn Mem 89: 285-292.

Woolf NJ, Milov AM, Schweitzer ES, Roghani A. 2001. Elevation of nerve growth factor and antisense knockdown of TrkA receptor during contextual memory consolidation. J Neurosci 21: 1047-1055.
Xia SZ, Feng CH, Guo AK. 1998. Multiple-phase model of memory consolidation confirmed by behavioral and pharmacological analyses of operant conditioning in Drosophila. Pharmacol Biochem Behav 60: $809-816$.

Xu T, Yu X, Perlik AJ, Tobin WF, Zweig JA, Tennant K, Jones T, Zuo Y. 2009. Rapid formation and selective stabilization of synapses for enduring motor memories. Nature 462: 915-919.

Yang G, Pan F, Gan WB. 2009. Stably maintained dendritic spines are associated with lifelong memories. Nature 462: 920-924.

Yao H, Labudda K, Rim C, Capodieci P, Loda M, Stork PJS. 1995. Cyclic adenosine-monophosphate can convert epidermal growth-factor into a differentiating factor in neuronal cells. J Biol Chem 270: 20748-20753.

Ye X, Schobe JL, Sharma SK, Marina A, Carew TJ. 2008. Small G proteins exhibit pattern sensitivity in MAPK activation during the induction of memory and synaptic facilitation in Aplysia. Proc Natl Acad Sci 105: 20511-20516.

Ye X, Marina A, Carew TJ. 2012. Local synaptic integration of mitogen-activated protein kinase and protein kinase A signaling mediates intermediate-term synaptic facilitation in Aplysia. Proc Natl Acad Sci 109: 18162-18167.

Yin JC, Wallach JS, Del Vecchio M, Wilder EL, Zhou H, Quinn WG, Tully T. 1994. Induction of a dominant negative CREB transgene specifically blocks long-term memory in Drosophila. Cell 79: 49-58.

Yue JB, Mulder KM. 2000. Requirement of Ras/MAPK pathway activation by transforming growth factor $\beta$ for transforming growth factor $\beta(1)$ production in a Smad-dependent pathway. J Biol Chem 275: 30765-30773.

Zhang F, Endo S, Cleary LJ, Eskin A, Byrne JH. 1997. Role of transforming growth factor- $\beta$ in long-term synaptic facilitation in Aplysia. Science 275: $1318-1320$.

Zhao MR, Li D, Shimazu K, Zhou YX, Lu B, Deng CX. 2007. Fibroblast growth factor receptor- 1 is required for long-term potentiation, memory consolidation, and neurogenesis. Biol Psychiatry 62: $381-390$.

Zheng WH, Quirion R. 2004. Comparative signaling pathways of insulin-like growth factor- 1 and brain-derived neurotrophic factor in hippocampal neurons and the role of the PI3 kinase pathway in cell survival. J Neurochem 89: 844-852.

Zheng XY, Wang J, Haerry TE, Wu AYH, Martin J, O'Connor MB, Lee CHJ, Lee T. 2003. TGF- $\beta$ signaling activates steroid hormone receptor expression during neuronal remodeling in the Drosophila brain. Cell 112: $303-315$.

Zweifel LS, Kuruvilla R, Ginty DD. 2005. Functions and mechanisms of retrograde neurotrophin signalling. Nat Neurosci 6: 615-625.

Received April 6, 2013; accepted in revised form July 8, 2013. 


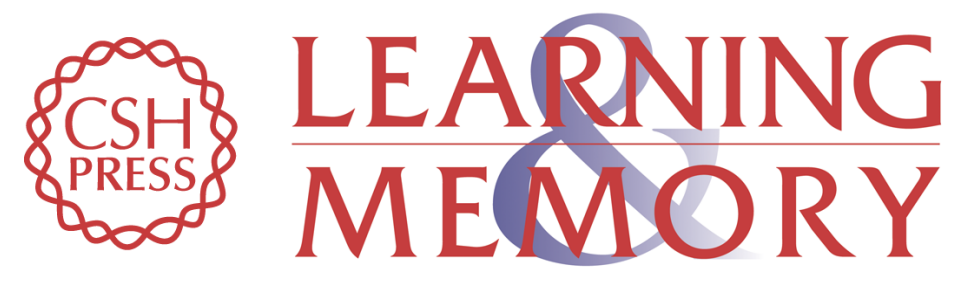

\section{Growth factor signaling and memory formation: temporal and spatial integration of a molecular network}

Ashley M. Kopec and Thomas J. Carew

Learn. Mem. 2013, 20:

Access the most recent version at doi:10.1101//m.031377.113

\begin{aligned} & \hline References $\begin{array}{l}\text { This article cites } 156 \text { articles, } 51 \text { of which can be accessed free at: } \\ \text { http://learnmem.cshlp.org/content/20/10/531.full.html\#ref-list-1 }\end{array} \\ & \begin{array}{r}\text { Creative } \\ \text { Commons } \\ \text { License }\end{array} \begin{array}{l}\text { This article is distributed exclusively by Cold Spring Harbor Laboratory Press for the } \\ \text { first } 12 \text { months after the full-issue publication date (see } \\ \text { http://learnmem.cshlp.org/site/misc/terms.xhtml). After } 12 \text { months, it is available under } \\ \text { a Creative Commons License (Attribution-NonCommercial 3.0 Unported), as } \\ \text { described at http://creativecommons.org/licenses/by-nc/3.0/. }\end{array} \\ & \begin{array}{c}\text { Receive free email alerts when new articles cite this article - sign up in the box at the } \\ \text { top right corner of the article or click here. }\end{array} \\ &$ Service \end{aligned} 